\title{
Root-derived organic matter confines sponge community composition in mangrove ecosystems
}

\author{
Ellard R Hunting*, Selma M Ubels, Michiel HS Kraak and Harm G van der Geest
}

\begin{abstract}
Introduction: Caribbean mangrove-associated sponge communities are very distinct from sponge communities living on nearby reefs, but the mechanisms that underlie this distinction remain uncertain. It has been hypothesized that dissolved organic matter (DOM) leaching from mangrove roots and the ability of mangrove-associated spongebacterial consortia to degrade mangrove DOM may cause this distinction.

Methods: This study tested whether mangrove DOM, leaching from mimicry substrates or directly injected in sponge tissue, affected the performance of a reef and a mangrove sponge species.

Results: Controls and the mangrove sponge remained unaffected by mangrove DOM leaching from mimicry substrates or directly injected in sponge tissue, but the reef species showed substantial necrosis when exposed to mangrove DOM.

Conclusions: Results presented in this study suggest that mangrove DOM confines the composition of sponge communities in mangrove ecosystems, explaining the exclusion of typical reef species and the adjacent occurrence of distinct sponge communities.
\end{abstract}

Keywords: Dissolved organic matter, Mangrove root, Necrosis, Polyphenols, Sponges, Reef

\section{Introduction}

Submerged roots of mangroves along (sub-) tropical Caribbean coasts serve as a substrate that is dominated by sponges. Mangrove-associated sponge communities are relatively species poor and distinct from the diverse sponge communities living on nearby reefs (e.g. van Soest 1978, 1980, 1984; Wulff 2004; Diaz et al. 2012). However, the mechanisms that underlie this distinction remain uncertain (for review, see Wulff 2012). Transplantation experiments of typical reef sponges to mangrove roots revealed that reef species deteriorated quickly after transplantation to coastal mangrove roots (Farnsworth and Ellison 1996; Wulff 2004; Pawlik et al. 2007), where the root substrate is critically important in limiting survival of reef species in mangrove systems (Hunting et al. 2013), while mangrove species remain unaffected. However, the question remains what causes the typically observed deterioration of reef species.

\footnotetext{
* Correspondence: E.R.Hunting@uva.nl

University of Amsterdam, Aquatic Ecology and Ecotoxicology, Institute for Biodiversity and Ecosystem Dynamics (IBED-AEE), Sciencepark 904, NL-1098 $\mathrm{XH}$, Amsterdam, The Netherlands
}

Dissolved organic matter (DOM) is a primary food source for sponge-bacterial consortia (de Goeij et al. 2008a, b), and it has been hypothesized that DOM leaching from mangrove roots plays an important role in structuring mangrove sponge community composition (Hunting et al. 2010b). Mangrove DOM consists mainly of tannins and polyphenolic compounds (Maie and Jaffe 2006), which are structurally complex and recalcitrant to biodegradation (Field and Lettinga 1992; Koch et al. 2005; Kristensen et al. 2008), thereby reducing mangrove palatability and inhibiting growth of fouling organisms on mangrove roots (e.g., Schmitt et al. 1998). A limited number of bacterial and fungal species are able to degrade complex polyphenols and tannins (Bhat et al. 1998). Therefore, the ability of mangrove-associated spongebacterial consortia to degrade mangrove DOM may explain the persistence of mangrove species in mangrove ecosystems, while the inability to degrade mangrove DOM could potentially hamper fouling of roots by reef species. However, this remains to be proven experimentally. This study therefore aimed to test whether mangrove DOM leachates from roots are responsible for the observed

\section{空}


deterioration of reef species transplanted to mangrove roots. To this end, we (1) transplanted a typical reef species and a typical mangrove species to mimicry substrates containing mangrove root extract and to control substrates without extract; and (2) injected mangrove DOM directly into tissues of both sponge species.

\section{Methods}

\section{Study site and sponge collection}

This study was conducted in Curaçao, N.A., southern Caribbean, in February and March 2013. The selected species included the mangrove sponge Tedania ignis, collected from the inner bays Spaanse Water and Piscaderbaai, and the reef sponge Desmapsamma anchorata, collected at the site where the transplantation experiment was performed: the shallow reefs in front of the research facility of Carmabi (Caribbean Research and Management of Biodiversity). Both species were chosen for their fast growth (Wulff
2005, 2010). For detailed maps of the study sites, see Hunting et al. (2008, 2010a) and De Goeij et al. (2008b).

\section{Transplantation experiment}

The effect of mangrove DOM on sponges was assessed with artificial substrates made from agar that allows mangrove root extracts to slowly diffuse into the overlying water (e.g., Henrikson and Pawlik 1995; Browne and Zimmer 2001; Hunting et al., 2010a). Each mimicry gel was prepared in plastic containers (volume $100 \mathrm{~cm}^{3}$ ) and consisted of 3\% agar (Molecular Genetics/Granulated, Roth, Germany) and $1 \mathrm{~mL}$ of mangrove root extract, added to the agar suspension at $\sim 50^{\circ} \mathrm{C}$. Mangrove DOM was extracted from freeze-dried and ground Rhizophora mangle roots (40 g dry weight) with $70 \%$ aqueous acetone for $48 \mathrm{~h}$. Root material was subsequently discarded, and the extract-containing acetone was centrifuged (4,000 rpm for $15 \mathrm{~min}$ ) and air-dried in a flow cabinet.
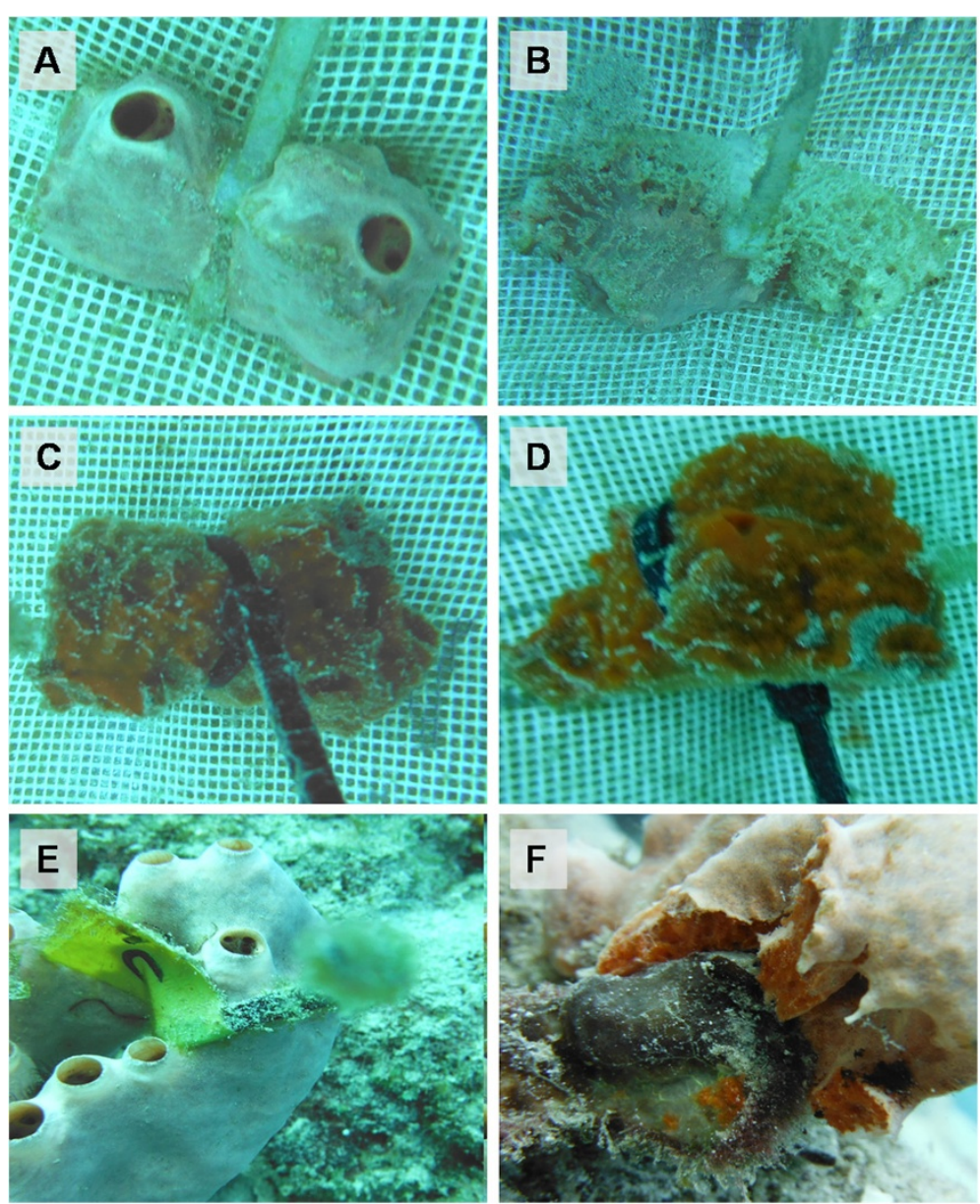

Figure 1 Responses of mangrove and reef sponges to mangrove-derived organic matter. Photographic recordings of the development of the reef sponge $D$. anchorata after transplantation to $(\mathbf{A})$ control gels without mangrove root extract and (B) mimicry gels containing mangrove root extract. T. ignis after transplantation to $(\mathbf{C})$ control gels without mangrove root extract and (D) mimicry gels containing mangrove root extract. Direct effects of the injection of $(\mathbf{E})$ seawater and $(\mathbf{F})$ dilute mangrove root extract on D. anchorata. Photographs were taken on day 7. The photographs are representative for each treatment $(n=5)$. 
The remaining pellet was subsequently resuspended in $100 \mathrm{~mL}$ deionized water. Gels were covered with plankton net (mesh size $2.0 \mathrm{~mm}$ ) to facilitate attachment of sponge transplants with plastic cable ties (Ellison et al. 1996). Five specimens of both $T$. ignis and D. anchorata $\left(2-3 \mathrm{~cm}^{3}\right)$ were transplanted to gels containing mangrove DOM, while an additional five specimens of both species were transplanted to gels without mangrove DOM as control. Transplants were evaluated for percent tissue necrosis (formation of white and black lesions) after 1 week and compared with a two-sample $z$-test.

\section{Injection experiment}

An additional experiment was performed to assess the direct effect of mangrove DOM on sponges by injecting mangrove DOM in sponge tissues. Five specimens of both $T$. ignis and $D$. anchorata were in situ injected with dilute (1:50) mangrove extract, and an additional five specimens of both species were injected with seawater as control. Injected sponges were evaluated for percent tissue necrosis (formation of white and black lesions) after 1 week and compared with a two-sample $z$-test.

\section{Results and discussion}

All specimens of the typical reef species $D$. anchorata transplanted to control substrates without mangrove DOM developed very well (Figure 1A). In contrast, $60 \%$ of the specimens transplanted to substrates containing mangrove DOM showed substantial (40-100\% of the tissue) necrosis (white lesions) after 1 week (Figure 1D), suggesting that mangrove DOM significantly affected the performance of $D$. anchorata (two-sample $z$-test, $z=2.1$, $p=0.0384$ ). This response is in agreement with previous observations on reef sponges transplanted to mangrove roots (Farnsworth and Ellison 1996; Wulff 2004; Pawlik et al. 2007; Hunting et al. 2013). The mangrove sponge $T$. ignis did not reveal any sign of necrosis on substrates containing mangrove DOM or on the control substrates (Figure 1B,D). Similarly, injection of dilute mangrove extract in $D$. anchorata resulted in necrosis in all specimens, primarily various degrees of black lesions surrounding the site of injection, and altered shape in two specimens, while controls injected with seawater remained unaffected (Figure 1C,F). All T. ignis specimens remained unaffected by the injection of both dilute mangrove DOM and seawater (not shown). Injection of mangrove DOM also significantly affected the performance of $D$. anchorata (two-sample $z$-test, $z=3.2, p=0.0016$ ).

The present study provided experimental evidence that mangrove DOM can exert negative effects on reef sponges, while mangrove-associated sponges remain unaffected. It has been demonstrated that mangrovederived organic matter is a major carbon source for sponges living in mangrove ecosystems (Granek et al.
2009), while reef species feed mainly on DOM derived from crustose coralline algae and coral mucus (van Duyl et al. 2011). Sponges attached to mangrove roots are in the direct vicinity of root leachates and exposed to high concentrations of DOM when DOM accumulates in the surrounding water. Our observations thus suggest that mangrove DOM prevents typical reef species from thriving in mangrove ecosystems and support the notion that the composition of DOM can be of general importance to the performance of sponge-bacterial consortia (Hunting et al. 2013).

\section{Conclusions}

This study aimed to test whether mangrove DOM leachates from roots are responsible for the typically observed deterioration of reef species transplanted to mangrove roots. We observed that mangrove DOM induced necrosis in a reef sponge, while a mangrove-associated sponge remained unaffected. The inability of reef species to cope with mangrove DOM may therefore confine the composition of mangrove-associated sponge communities, explaining the exclusion of typical reef species and the adjacent occurrence of distinct sponge communities.

Competing interests

The authors declared they have no competing interests.

\section{Authors' contributions}

EH conceived the study. SU performed the experiment. EH, SU, MK and HG wrote the paper. All authors read and approved the final manuscript.

\section{Acknowledgements}

Fieldwork was conducted at Carmabi Research Center, Curacao, N. A., and was funded by the Schure-Beijerinck-Popping Fund of the Dutch Royal Academy of Science (KNAW). The authors express their gratitude to two anonymous referees for their constructive comments on an earlier draft of this article.

Received: 21 March 2013 Accepted: 17 May 2013

Published: 6 June 2013

\section{References}

Bhat TK, Singh B, Sharma OP (1998) Microbial degradation of tannins-a current perspective. Biodegradation 9:343-357

Browne KA, Zimmer RK (2001) Controlled field release of a waterborne chemical signal stimulates planktonic larvae to settle. Biol Bull 200:87-89

de Goeij JM, Moodley L, Houtekamer M, Carballeira NM, van Duyl FC (2008a) Tracing 13C-enriched dissolved and particulate organic carbon in the bacteria-containing coral reef sponge Halisarca caerulea: evidence for DOMfeeding. Limnol Oceanogr 53:1376-1386

de Goeij JM, van den Berg H, van Oostveen MM, Epping EHG, van Duyl FC (2008b) Major bulk dissolved organic carbon (DOC) removal by encrusting coral reef cavity sponges. Mar Ecol Prog Ser 357:139-151

Diaz M (2012) Mangrove and coral reef sponge faunas: untold stories about shallow water Porifera in the Caribbean. Hydrobiologia 687:179-190

Ellison AM, Farnsworth EJ, Twilley RR (1996) Facultative mutualism between red mangroves and root-fouling sponges in Belizean mangal. Ecology 77(8):2431-2444

Farnsworth EJ, Ellison AM (1996) Scale-dependent spatial and temporal variability in biogeography of mangrove root epibionts communities. Ecol Monogr 66:45-66

Field JA, Lettinga G (1992) Toxicity of tannic compounds to microorganisms. In: Hemmingway RW, Laks PE (eds) Plant polyphenols: synthesis, properties, significance. Plenum, New York, pp 673-692 
Granek EF, Compton JE, Phillips DL (2009) Mangrove-exported nutrient incorporation by sessile coral reef invertebrates. Ecosystems 12:462-472

Henrikson AA, Pawlik JR (1995) A new antifouling assay method: Results from field experiments using extracts of four marine organisms. J Exp Mar Biol Ecol 194:157-165

Hunting ER, van Soest RWM, van der Geest HG, Vos A, Debrot AO (2008) Diversity and spatial heterogeneity of mangrove associated sponges of Curaçao and Aruba. Contrib Zool 77:205-215

Hunting ER, van der Geest HG, Krieg AJ, van Mierlo MBL, van Soest RWM (2010a) Mangrove-sponge associations: a possible role for tannins. Aquat Ecol 44:679-684

Hunting ER, de Goeij JM, Asselman M, van Soest RWM, van der Geest HG (2010b) Degradation of mangrove-derived organic matter in mangrove associated sponges. Bull Mar Sci 86:871-877

Hunting ER, Franken O, Knopperts F, Kraak MHS, Vargas R, Röling WFM, van der Geest HG (2013) Substrate as a driver of sponge distributions in mangrove ecosystems. Mar Ecol Prog Ser. doi:10.3354/meps10376, in press

Koch BP, Harder J, Lara RJ, Kattner G (2005) The effect of selective microbial degradation on the composition of mangrove derived pentacyclic triterpenols in surface sediments. Org Geochem 36:273-285

Kristensen E, Bouillon S, Dittmar T, Marchand C (2008) Organic carbon dynamics in mangrove ecosystems: a review. Aquat Bot 89:201-219

Maie N, Jaffe R (2006) Quantitative and qualitative aspects of dissolved organic carbon leached from senescent plants in an oligotrophic wetland. Biogeochem 78:285-314

Pawlik JR, McMurray SE, Henkel TP (2007) Abiotic factors control sponge ecology in Florida mangroves. Mar Ecol Prog Ser 339:93-98

Schmitt TM, Lindquist N, Hay ME (1998) Seaweed secondary metabolites as antifoulants: effects of Dictyota spp. diterpenes on survivorship, settlement, and development of marine invertebrate larvae. Chemoecology 8:125-131

van Duyl FC, Moodley L, Nieuwland G, IJzerloo L, van Soest RWM, Houtekamer M, Meesters EH, Middelburg JJ (2011) Coral cavity sponges depend on reefderived food resources: stable isotope and fatty acid constraints. Mar Biol 158:1653-1666

van Soest RWM (1978) Marine sponges from Curaçao and other Caribbean islands. Part I. Keratosa. In: Hummelinck PW, Van der Steen $\sqcup$ (eds) Studies on the fauna of Curaçao and other Caribbean islands, 56th edn. Uitgaven van de Natuurwetenschappelijke Studiekring voor Suriname en de Nederlandse Antillen, Utrecht, pp 1-94

van Soest RWM (1980) Marine sponges from Curaçao and other Caribbean islands. Part II. Haplosclerida. In: Hummelinck PW, Van der Steen LJ (eds) Studies on the fauna of Curaçao and other Caribbean islands, 62nd edn. Uitgaven van de Natuurwetenschappelijke Studiekring voor Suriname en de Nederlandse Antillen, Utrecht, pp 1-173

van Soest RWM (1984) Marine sponges from Curaçao and other Caribbean islands. Part III. Poecilosclerida. In: Hummelinck PW, Van der Steen L (eds) Studies on the fauna of Curaçao and other Caribbean islands, 66th edn. Uitgaven van de Natuurwetenschappelijke Studiekring voor Suriname en de Nederlandse Antillen, Utrecht, pp 1-167

Wulff JL (2004) Sponges on mangrove roots, Twin Cays, Belize: Early stages of community assembly. Atoll Res Bull 519:1-10

Wulff $J L$ (2005) Trade-offs in resistance to competitosrs and predators, and their effects on the diversity of tropical marine sponges. J Anim Ecol 74:313-321

Wulff $\mathrm{JL}$ (2010) Regeneration of sponges in ecological context: is regeneration an integral part of life history and morphological strategies? Integr Comp Biol 50:494-505

Wulff JL (2012) Ecological interactions and the distribution, abundance, and diversity of sponges. Adv Mar Biol 61:273-rpe344

doi:10.1186/2192-1709-2-14

Cite this article as: Hunting et al:: Root-derived organic matter confines sponge community composition in mangrove ecosystems. Ecological Processes 2013 2:14

\section{Submit your manuscript to a SpringerOpen ${ }^{\circ}$ journal and benefit from:}

- Convenient online submission

- Rigorous peer review

- Immediate publication on acceptance

- Open access: articles freely available online

- High visibility within the field

- Retaining the copyright to your article

Submit your next manuscript at $\mathbf{s p r i n g e r o p e n . c o m ~}$ 